\title{
PREREQUISITES FOR STRATEGIC MANAGEMENT OF THE AIR TRANSPORT ENTERPRISES DEVELOPMENT
}

\author{
๑2021 SHKODA T. N.
}

UDC 330.101.541:339.5

JEL: 01; L93; R41

\section{Shkoda T. N. Prerequisites for Strategic Management of the Air Transport Enterprises Development}

The global crisis caused by the COVID-19 pandemic has suspended not only the development of the aviation sector, but also the global economy in general. The possibility of acquiring the pre-crisis level indicators by domestic air transport enterprises depends on the effective solution of problematic issues to increase their competitiveness in the liberalized aviation market. This publication is aimed at carrying out systematization and identifying the prerequisites for efficient strategic management of Ukrainian air transport enterprises on the basis of consideing modern challenges in the development of the air transport services market, the conditions and industry peculiarities of the activities of aviation business entities in Ukraine. According to the results of the conducted study, the list of obstacles that hinder the development of air transport in Ukraine are systematized. The identified sufficiently strong dependence of the added value created by domestic airlines on such factors as the amount of time worked, the number of airlines, the volumes of passenger transportation and the number of advanced technologies used, pointed out the expediency of taking into account the stimulating impact of these factors on the business activity of domestic air transport enterprises for the development of the national economy. The results of the study of the prerequisites for increasing the competitiveness and development of air transport enterprises of Ukraine have testified to the need to create conditions for efficient strategic management of Ukrainian airlines, which together, due to the creation of additional jobs, as well as added value, have a direct impact on the formation of Ukraine's gross domestic product.

Keywords: air transport, liberalization, strategic management, airline, development tendencies, added value.

DOI: https://doi.org/10.32983/2222-4459-2021-3-75-80

Fig.: 6. Tabl.: 1. Bibl.: 10.

Shkoda Tetiana N. - D. Sc. (Economics), Associate Professor, Associate Professor of the Department of Personnel Management and Labour Economics, Kyiv National Economic University named after V. Hetman (54/1 Peremohy Ave., Kyiv, 03057, Ukraine)

E-mail: shkoda-tetiana@kneu.edu.ua

ORCID: https://orcid.org/0000-0003-1016-4853

Researcher ID: https://publons.com/researcher/2591251/tetiana-shkoda/

Scopus Author ID: https://www.scopus.com/authid/detail.uri?authorld=57211859220

УДК 330.101.541:339.5

JEL: 01; L93; R41

Шкода Т. Н. Передумови стратегічного управління розвитком авіатранспортних підприємств

Світова криза, спричинена пандемією COVID-19, призупинила не тільки розвиток авіаційного сектора, але й світову економіку загалом. Можливість набуття вітчизняними авіатранспортними підприємствами показників докризового рівня залежіть від ефекттивного вирішення проблемних питань підвищення їх конкурентоспроможності на лібералізованому авіаційному ринку. Метою даної роботи є проведення систематизації та виявлення передумов ефекттивного стратегічного управління авіатранспортними підприємствами України на основі урахування сучасних викликів розвитку ринку авіатранспортних послуг, а також умов і галузевих особливостей діяльності суб'єктів авіаційного бізнесу в Україні. за результатами проведеного дослідження систематизовано перелік перешкод, що стримують розвиток авіаційного транспорту України. Виявлена достатньо сильна залежність доданої вартості, створеної вітчизняними авіакомпаніями, від таких чинників, як кількість відпрацьованого часу, кількість авіакомпаній, обсяги перевезення пасажирів і кількість використовуваних передових технологій, вказала на доцільність урахування стимулюючого впливу цих факторів ділової активності вітчизняних авіатранспортних підприємств на розвиток національної економіки. Результати дослідження передумов підвищення конкурентоспроможності та розвитку авіатранспортних підприємств України засвідчили необхідність створення умов для ефективного стратегічного управління авіапідприємствами України, які в сукупності, за рахунок створення додаткових робочих місць, а також доданої вартості, чинять безпосередній вплив на формування валового внутрішнього продукту України.

Ключові слова: авіаційний транспорт, лібералізація, стратегічне управління, авіакомпанія, тенденції розвитку, додана вартість.

Рис.: 6. Табл.: 1. Бібл.: 10.

Шкода Тетяна Никодимівна - доктор економічних наук, доцент, доцент кафедри управління персоналом та економіки праці, Київський національний економічний університет ім. В. Гетьмана (просп. Перемоги, 54/1, Київ, 03057, Україна)

E-mail: shkoda-tetiana@kneu.edu.ua

ORCID: https://orcid.org/0000-0003-1016-4853

Researcher ID: $h$ ttps://publons.com/researcher/2591251/tetiana-shkoda/

Scopus Author ID: https://www.scopus.com/authid/detail.uri?authorld=57211859220

$\mathrm{T}$ The transformation of the Ukrainian economy and the formation of market relations make it necessary to study the problems of survival and further development of enterprises in an unstable external environment. No enterprise can remain in a state of stable equilibrium, but has to constantly develop, otherwise it will cease to exist. This requirement is more relevant today than ever for Ukrainian air transport companies. The global crisis caused by the COVID-19 pandemic has suspended not only the development of the aviation sector, but that of the global economy, as a whole. The capability of domestic air transport enterprises to obtain 
pre-crisis indicators depend on the effective solution of problematic issues in increasing their competitiveness in the liberalized aviation market. The results of the developed instruments for the effective strategic management of Ukrainian aviation enterprises will have a positive impact on the state of development of the Ukrainian air transport industry even after Ukraine's signing the agreement with the EU on European Common Aviation Area.

The organizational and economic components of strategic management at air transport enterprises were developed in the works by such domestic scientists as G. V. Zhavoronkova, Yu. F. Kulaev, V. M. Zagorulko, G. M. Yun, V. G. Koba., T. I. Oleshko, I. O. Geiets, I. P. Sadlovska, O. V. Arefieva, M. Yu. Grygorak, M. V. Kolesnik, M. V. Korzh, V. O. Novak, L. L. Lytvynenko, O. M. Kyrylenko and others. But at present, the systematization of prerequisites for ensuring effective strategic management of enterprises in the air transport industry requires rethinking and elaboration, taking into account the existing challenges, e. g. the rapid development of liberalizing processes in the air transport industry.

The purpose of the work is to systematize and identify the prerequisites for the effective strategic management of air transport enterprises in Ukraine, taking into account the current challenges of the air transport services market development, as well as the conditions and specific features of the activities of aviation business entities in Ukraine.

\section{Research methods}

During the study, both general scientific and specific methods of economic analysis were used, namely: structural and logical, factor, and correlation-regression analysis, as well as analytical alignment.

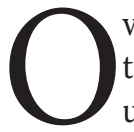
ver the past decades, significant changes have taken place in the air transport of Ukraine. It used to be sctrictly public sector and air transport was considered to be a type of public service, but now the State plays the intermediary role in the marketoriented transport sector and monitors its compliance with rules, including those established by international regulatory organizations.

The dynamic growth of demand present in the air transportation market until February 2020, indicated, first of all, positive changes in recent years not only in Ukraine's economy, but also in the functioning of the aviation market, namely, in its gradual liberalization, thus opening access for foreign low-cost airlines, whose share in the international segment of Ukraine's air transportation increased significantly in 2019 [1-3]. Currently, the domestic aviation market has been protected from mass foreign expansion by intergovernmental agreements previously concluded by Ukraine with each of the EU countries. They stipulated the number of carriers appointed by the parties, and quotas for the number of flights between states [4]. However, in recent years, bilateral agreements on air traffic between Ukraine and other coun- tries, the EU and the United States, in particular, , have been gradually liberalized [5]. Given the prospects of the Ukrainian market, European global airlines have tried to expand their presence in it. Large fleets of aircraft allow them to fly much more often, and good working capital availability has helped reduce fares for flights to and from Ukraine. If we turn to statistics, then back in 2007, only three Ukrainian airlines were among the top ten users of Ukrainian airspace [6, p. 314], and according to the results of 2019, the number remained the same, but their list was modified [7], as shown in Tbl. 1.

Table 1

Main users of Ukrainian airspace

\begin{tabular}{|c|c|c|}
\hline No. & 2007 & 2019 \\
\hline 1 & Aerosvit (Ukraine) & $\begin{array}{l}\text { Ukraine International } \\
\text { Airlines (Ukraine) }\end{array}$ \\
\hline 2 & Lufthansa (Germany) & $\begin{array}{l}\text { Turk Hava Yollari A.O. } \\
\text { (Turkey) }\end{array}$ \\
\hline 3 & Emirates (U. A. E.) & $\begin{array}{l}\text { Wizz Air Hungary LLC } \\
\text { (Hungary) }\end{array}$ \\
\hline 4 & $\begin{array}{l}\text { Ukraine International } \\
\text { Airlines (Ukraine) }\end{array}$ & $\begin{array}{l}\text { OAO Aviakompaniya } \\
\text { Belavia (Belarus) }\end{array}$ \\
\hline 5 & Aeroflot (Russia) & $\begin{array}{l}\text { LOT Polish Airlines } \\
\text { (Poland) }\end{array}$ \\
\hline 6 & $\begin{array}{l}\text { United States Air Force } \\
\text { (USA) }\end{array}$ & $\begin{array}{l}\text { SkyUp Airlines LLC } \\
\text { (Ukraine) }\end{array}$ \\
\hline 7 & $\begin{array}{l}\text { Austrian Airlines } \\
\text { (Austria) }\end{array}$ & $\begin{array}{l}\text { Wind rose Aviation } \\
\text { Company (Ukraine) }\end{array}$ \\
\hline 8 & DonbassAero (Ukraine) & Ryanair LTD (Ireland) \\
\hline 9 & $\begin{array}{l}\text { Singapore Airlines (Sin- } \\
\text { gapore) }\end{array}$ & $\begin{array}{l}\text { Azur Air Ukraine Air- } \\
\text { lines LLC }\end{array}$ \\
\hline 10 & KLM (Netherlands) & $\begin{array}{l}\text { Qatar Airways CO } \\
\text { (Qatar) }\end{array}$ \\
\hline
\end{tabular}

The advantage of European Airlines is explained by of the fact that it has global route networks covering all the major cities of the world, and powerful base airports, or hubs that allow intercepting transit passenger flows that move between continents. In addition, as the history of the European Treaty on Open Skies shows, mainly those companies could successfully compete in the free market that managed to get stronger due to the reasonably protectionist policy of their states. And the countries that neglected this approach actually lost their national aviation [6, p. 315].

An appropriate solution to the problems of increasing the competitiveness of domestic air transportation is the creation of a national flagship air carrier. The second direction of ensuring the increasing in the competitiveness of the Ukrainian air transportation market is related to consolidating the image of Ukraine as an air transit state by concentrating transit transportation of passengers and cargo through the Boryspil State International Airport. However, securing Ukraine's image 
as an exclusively transit state will not help increase the competitiveness of Ukrainian airlines, and especially, regional airports . An important area of ensuring the airlines competitiveness growth is improving the safety of air transportation. Serious concern is caused by flights of the so-called "small aircraft", usually as part of the divisions of the Society for the Promotion of the Defense of Ukraine and the All-Ukrainian association called Aeroclubs of Ukraine [6, p. 316].

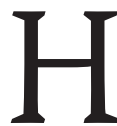
aving analyzed a wide range of problems hindering the development of air transport in Ukraine, we systematize the main ones as following: insufficient working capital at regional airports to maintain fixed assets in operational condition, carry out their modernization and renewal; physical deterioration and moral aging of the aircraft fleet of domestic airlines, and their low competitiveness; a significant number of small airlines that do not have their own fleet of aircraft, are not provided with financial resources and operate chaotically in the air transportation market. In addition, a significant number of airlines in the Ukrainian air transportation market and a small volume of traffic performed by most of them indicate a significant dispersion of the Ukrainian market and low efficiency of aviation activities. The reason for this is the fact that the principle of competitive selection of applicants is practically not used in state licensing and certification procedures, and permits for international air transportation are issued to companies that cannot properly use them and develop routes. There are no criteria that would determine the admission of carriers to perform a particular type of flight, depending on their financial situation. Nevertheless, the need for comprehensive reconstruction, which requires significant costs, remains to be the main problem of air transport in Ukraine ,. To ensure pre-crisis traffic volumes, domestic airports need to introduce investment models of public-private partnership.

Solving the identified obstacles will accelerate the development of the domestic air transport industry, which, due to the creation of additional jobs and added value, has a direct impact on the formation of Ukraine's gross domestic product. Thus, having modelled the influence of factors accompanying the business activity of domestic airlines, we have revealed a positive impact of the volume of passenger traffic, as well as cargo and mail traffic by air transport; the number of advanced technologies used in air transport; the number of airlines (Classification of types of economic activity, "CTEA" 51.10 and 51.21); hours worked; and the average number of full-time employees in air transport on the value added, created by domestic airlines (CTEA 51.10 and 51.21). The results of the dependency analysis are shown in Fig. 1 - Fig. 6.

As a result indicator, the added value rate (AV) of Ukrainian aviation transport according to the CTEA 51.10 (passenger aviation transport) and 51.21 (cargo aviation transport) for 2007-2019 was used based on the systematization of source arrays from the data sources $[9$;
10]. While conducting an experimental study, dynamic trend models were used, because in our case, the use of the analytical alignment method made it possible to determine the main development trends and establish the adequacy of the trend model of the process being studied, namely, how much the added value created by domestic airlines depends on the influence of a certain factor of activity of a certain time period (2007-2019).

By applying the analytical alignment method an important problem is solved, namely, the selection of a mathematical function for which the theoretical levels of the series are calculated. The trend model, in which the coefficient of determination had the highest value, became the most adequate one for each dependence assessed.

A correlation coefficient was also determined, which made it possible to measure the statistical dependence (the level of influence of the argument $x$ on the function $y$ ). The fact that the correlation coefficient can lie in the range from -1 to +1 was taken into account. Therefore, based on the value of the calculated correlation coefficient on the Chaddock scale, the conclusion was made as for the presence or absence of stochastic dependence: 1 ) from 0 to \pm 0.3 - absent; 2) from \pm 0.3 to \pm 0.5 - weak; 3) from \pm 0.5 to \pm 0.7 - average; 4) from \pm 0.7 to \pm 1 - strong.

$\mathrm{n}$ general, a fairly strong positive dependence of the added value created by domestic airlines on such factors as the amount of time worked (correlation coefficient $R=0.92$ ), the number of airlines (correlation coefficient $R=0.95$ ), the number of passengers transported (correlation coefficient $R=0.86$ ) and the number of advanced technologies used (correlation coefficient $R=0.90$ ), indicates the stimulating effect of the growth of business activity of domestic aviation transport on the national economy development.

Taking into account the identified patterns, as well as the revealed features of the current stage of air transport development mentioned above, we believe that the strategic positioning of air transport enterprises in Ukraine should be aimed at ensuring the strengthening of their economic interests, taking into account their contribution to the development of the country's economy as a whole. Therefore, state regulation of the air transport industry should take into account the identified stimulating factors and create favorable conditions for improving the effectiveness of strategic positioning of air transport enterprises in Ukraine. In general, Ukraine's European integration is necessary for domestic air carriers, but air traffic statistics indicate an increase in the volume of traffic by international airlines, and too much market liberalization can lead to the loss of domestic airlines' market positions.

\section{CONCLUSIONS}

The revealed strong positive dependence of the added value created by domestic airlines on such factors as the amount of time worked, the number of airlines, the 


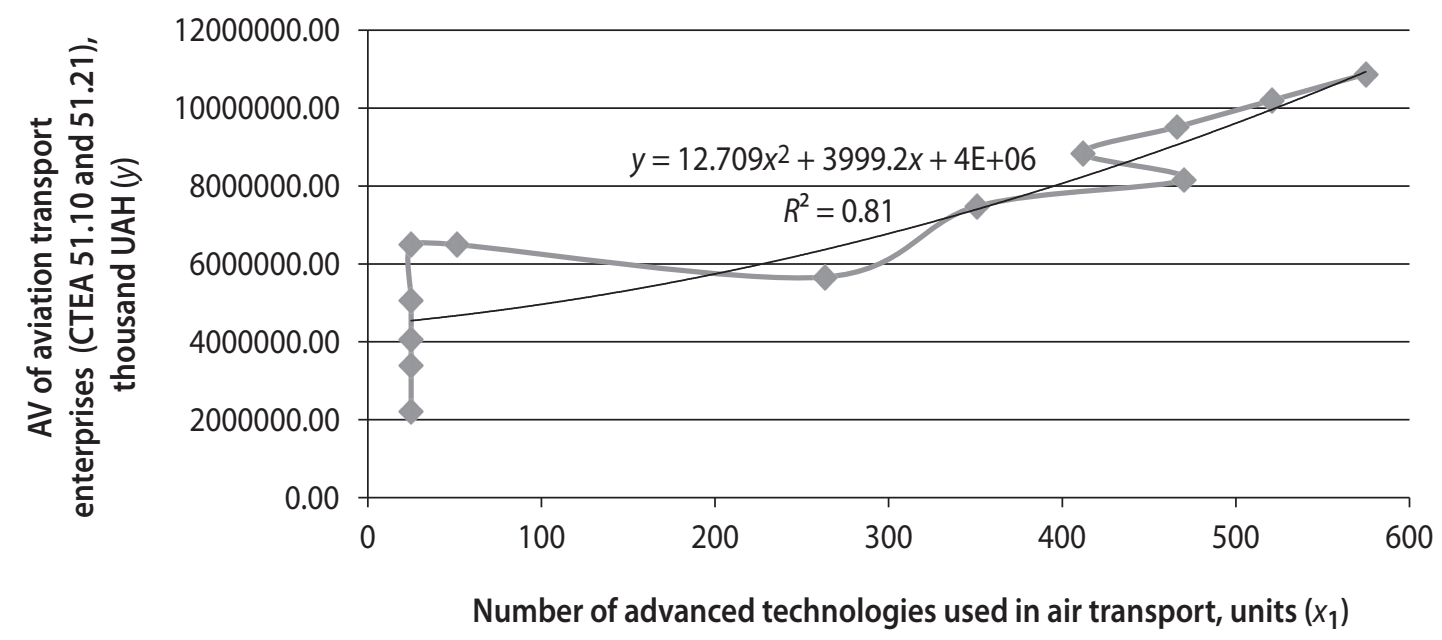

Fig. 1. Trend Model of the polynomial dependence of the resulting indicator y (AV of aviation transport enterprises (CTEA 51.10 and 51.21)) on the factor attribute $x_{1}$ (the number of advanced technologies used in aviation transport)

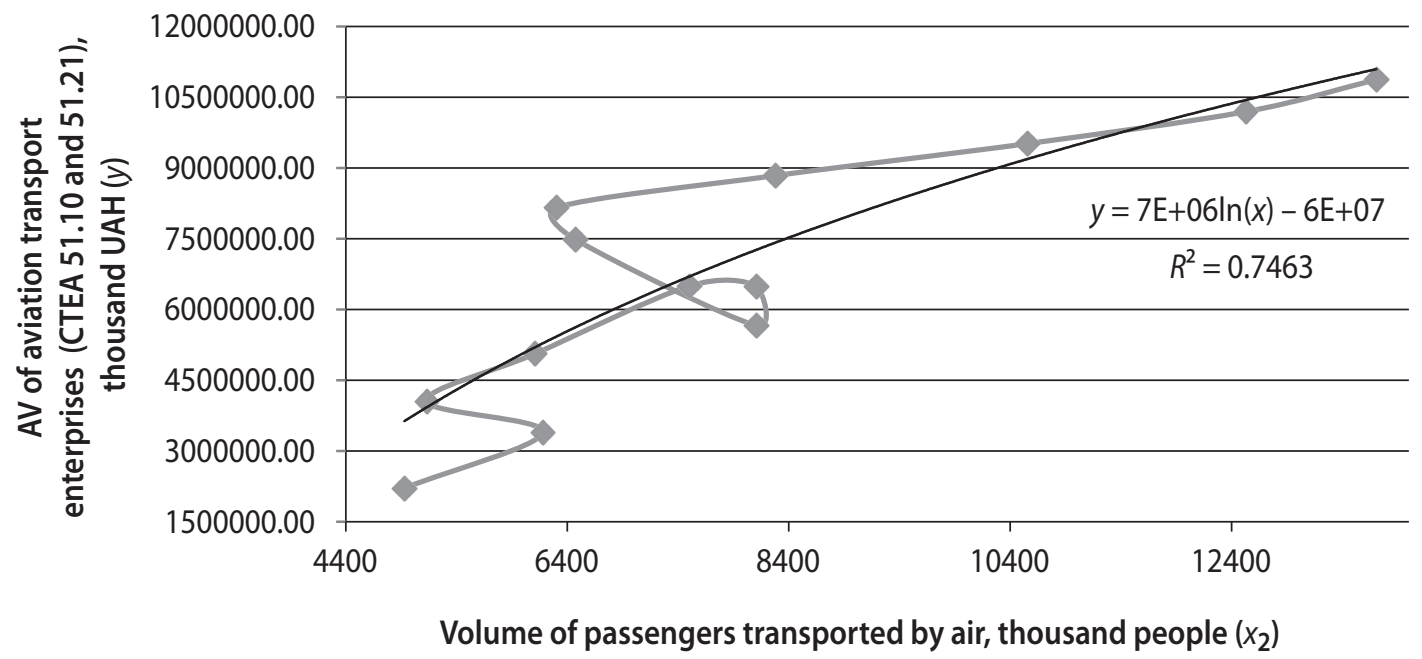

Fig. 2. Trend Model of the polynomial dependence of the resulting indicator $y$ (AV of aviation transport enterprises (CTEA 51.10 and 51.21)) on the factor feature $x_{2}$ (the number of passengers transported by air transport)

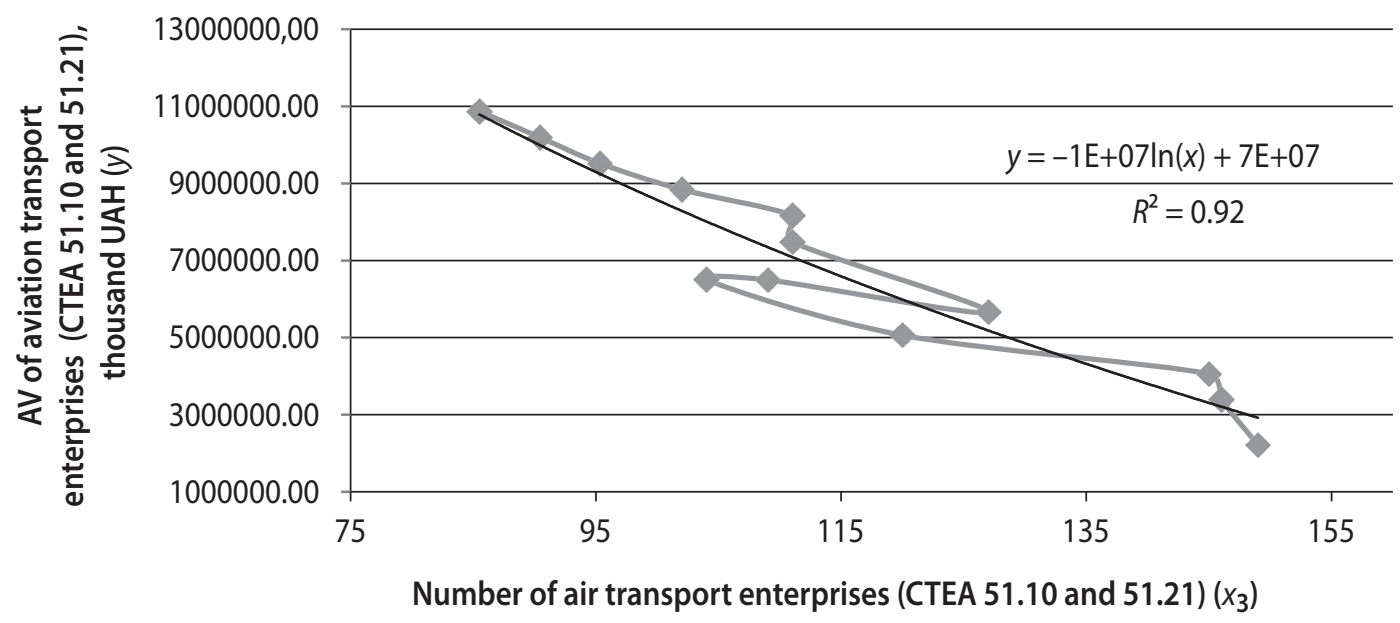

Fig. 3. Trend Model of the polynomial dependence of the resulting indicator $y$ (AV of aviation transport enterprises (CTEA 51.10 and 51.21)) on the factor feature $x_{3}$ (number of aviation transport enterprises) 


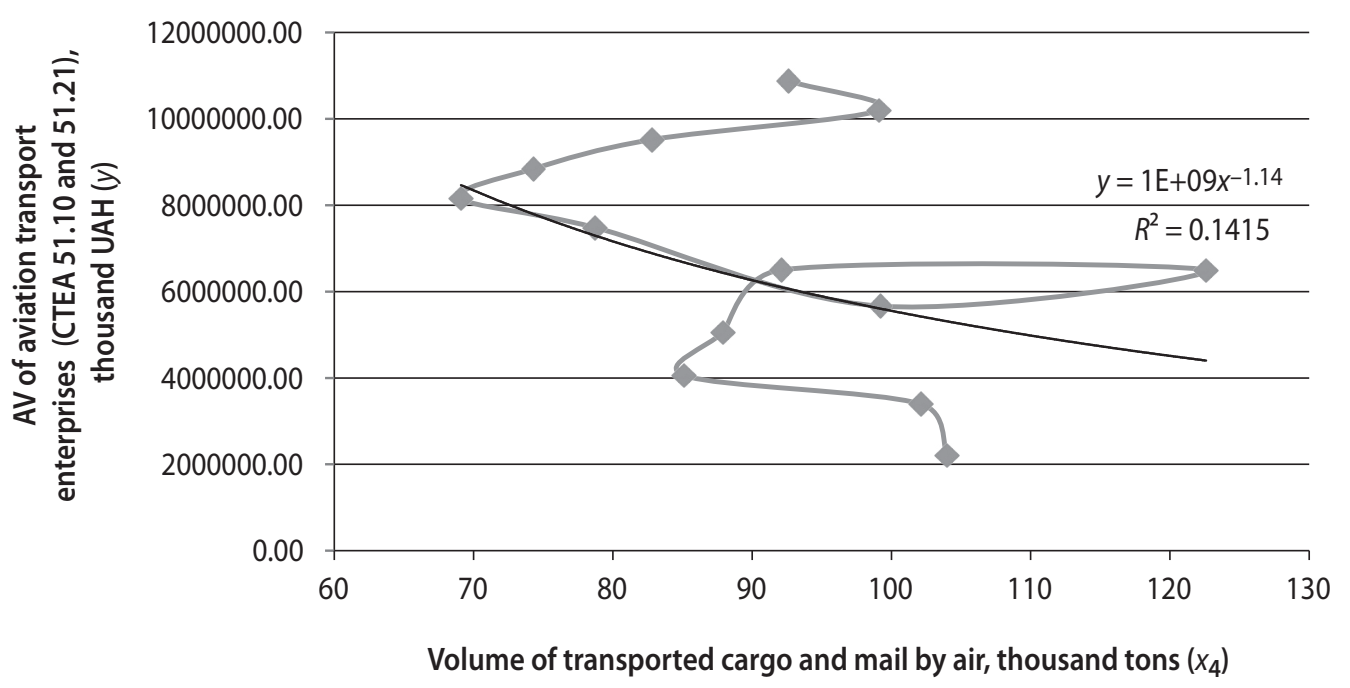

Fig. 4. Trend Model of the polynomial dependence of the resulting indicator y (AV of aviation transport enterprises (CTEA 51.10 and 51.21)) on the factor attribute $x_{4}$ (the volume of cargo and mail transported by air transport)

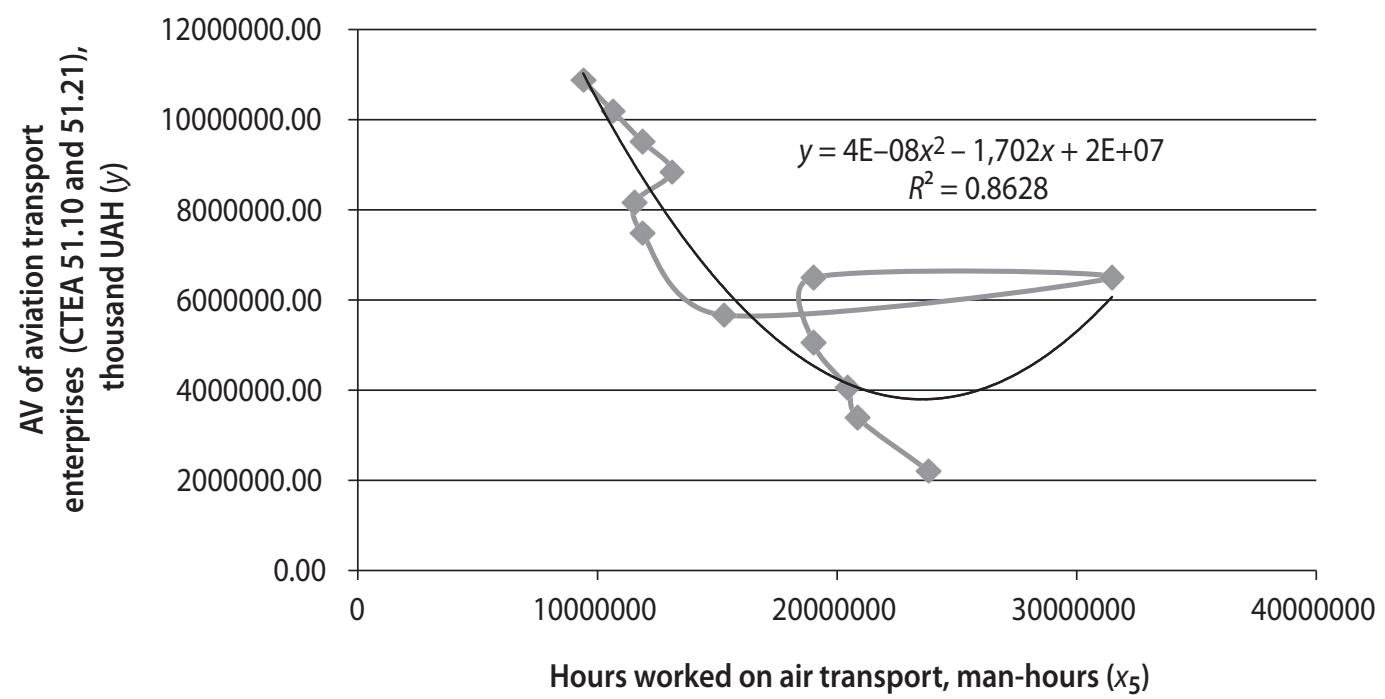

Fig. 5. Trend Model of the polynomial dependence of the resulting indicator $y$ (AV of aviation transport enterprises (CTEA 51.10 and 51.21)) on the factor attribute $x_{5}$ (hours worked for aviation transport)

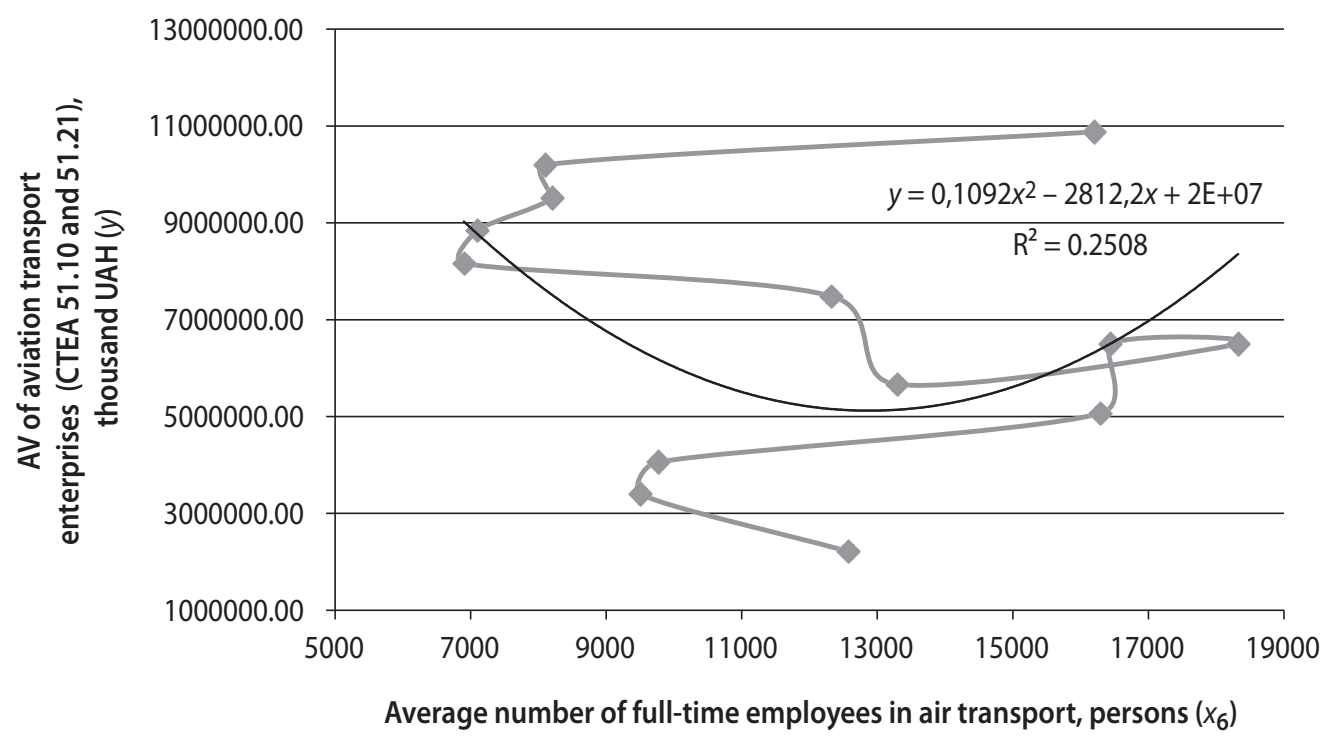

Fig. 6. Trend Model of polynomial dependence of the resulting indicator y (AV of aviation transport enterprises (CTEA 51.10 and 51.21)) on the factor feature $x_{6}$ (average number of employees at air transport enterprises) 
volume of passenger transportation and the number of advanced technologies used, showed the expediency of taking into account the stimulating effect made by such factors of the business activity of domestic air transport enterprises on the national economy development.

$\mathrm{T}$ The results of the study of the prerequisites for improving the competitiveness and development of Ukraine's air transport enterprises show the need to address the following issues that are part of the prerequisites list for effective strategic management of Ukrainian airlines: accelerating the implementation of Common Aviation Requirements of the European Union in Ukraine, improving national legislation in civil aviation and bringing it to the requirements of international standards, strengthening Ukraine's image as an air transit state by concentrating transit transportation of passengers and cargo through Boryspil State International Airport, bringing regional airports in line with European standards, attracting private investment in the development of airport infrastructure, maintaining competitiveness and protecting the economic interests of Ukrainian carriers in international air transport markets, expanding the presence of Ukrainian carriers on new international routes.

\section{LITERATURE}

1. Звіт Голови Державної авіаційної служби України за 2019 рік. URL: https://www.kmu.gov.ua/storage/app/ sites/1/17-civik-2018/zvit_2019/zvit-2019-avia.pdf

2. Savych O., Shkoda T. Trends of air transportation marm ket development in Ukraine. Innovative Marketing. 2020. Vol. 16. Is. 2. P. 29-42. DOI: http://dx.doi.org/10.21511/im.16(2).2020.03

3. Zhavoronkova G., Zhavoronkov V., Volvach N. Development of the aviation transportation market in Ukraine: problems and prospects. Trans \& Motauto World. 2018. Is. 3. P. 116-120. URL: https://stumejournals.com/journals/tm/2018/3/116.full.pdf

4. Михальченко І. Г. Оцінка рівня лібералізації авіаційних перевезень між Україною та країнами - членами Європейського Союзу. Економіка і суспільство. 2017. Вип. 8. С. 65-71. URL: https://economyandsoci: ety.in.ua/journals/8_ukr/11.pdf

5. Овсак О. П., Ліскович Н. Ю., Назаренко О. П. Україна на шляху лібералізації авіаційного простору. Інфраструктура ринку. 2020. Вип. 4. С. 3-13. DOI: https://doi.org/10.32843/infrastruct40-1

6. Жаворонкова Г. В., Садловська І.П., Шкода Т.Н., Жаворонков В. О. Стратегічне управління авіатранспортними підприємствами. Київ : Кондор, 2012.676 с.

7. Державне підприємство обслуговування повітряного руху України. URL: https:///uksatse.ua/index. php?s=7fafa5d747ed5296870f4e285d3e17df\&act=Pa $\mathrm{rt \& CODE}=247 \& \mathrm{id}=450$

8. Транспорт і зв'язок України 2018 : статистичний збірник / Державна слоужба статистики України.
Київ, 2019. 153 с. URL: http://www.ukrstat.gov.ua/ druk/publicat/kat_u/2019/zb/08/zb_tr2018pdf.pdf

9. Транспорт України 2019 : статистичний збірник / Державна слоужба статистики України. Київ, 2020. 114 c. URL: https://ukrstat.org/uk/druk/publicat/ kat_u/2020/zb/10/zb_trans_19.pdf

10. Шкода Т. Н. Стратегічне управління людським капіталом авіатранспортних підприємств : дис. ... д-ра екон. наук : 08.00.04; 08.00.07. Київ, 2018. 586 с.

\section{REFERENCES}

"Derzhavne pidpryiemstvo obsluhovuvannia povitrianoho rukhu Ukrainy" [State Enterprise for Air Traffic Services of Ukraine "UkSATSE"]. https:///uksatse.ua/ index.php?s=7fafa5d747ed5296870f4e285d3e17df\&a $c t=$ Part\&CODE $=247 \& i d=450$

Mykhalchenko, I. H. "Otsinka rivnia liberalizatsii aviatsiinykh perevezen mizh Ukrainoiu ta krainamy - chlenamy Yevropeiskoho Soiuzu" [Evaluation of the Air Liberalization between Ukraine and Member States of the European Union]. Ekonomika i suspilstvo, is. 8 (2017): 65-71. https://economyandsociety.in.ua/journals/8_ukr/11.pdf

Ovsak, O. P., Liskovych, N. Yu., and Nazarenko, O. P."Ukraina na shliakhu liberalizatsii aviatsiinoho prostoru" [Ukraine on the Path of Aviation Space Liberalization]. Infrastruktura rynku, no. 4 (2020): 3-13.

DOI: https://doi.org/10.32843/infrastruct40-1

Savych, O., and Shkoda, T. "Trends of air transportation market development in Ukraine". Innovative Marketing, vol. 16, no. 2 (2020): 29-42.

DOI: http://dx.doi.org/10.21511/im.16(2).2020.03

Shkoda, T. N. "Stratehichne upravlinnia liudskym kapitalom aviatransportnykh pidpryiemstv" [Strategic Human Capital Management of Air Transport Enterprises]: dys.... d-ra ekon. nauk:08.00.04;08.00.07, 2018.

"Transport i zviazok Ukrainy 2018 : statystychnyi zbirnyk" [Transport and Communications of Ukraine 2018: A Statistical Collection]. Derzhavna slouzhba statystyky Ukrainy. Kyiv, 2019. http://www.ukrstat.gov.ua/druk/ publicat/kat_u/2019/zb/08/zb_tr2018pdf.pdf

"Transport Ukrainy 2019: statystychnyi zbirnyk" [Transport of Ukraine 2019: A Statistical Collection]. Derzhavna slouzhba statystyky Ukrainy. Kyiv, 2020. https:// ukrstat.org/uk/druk/publicat/kat_u/2020/zb/10/zb_ trans_19.pdf

"Zvit Holovy Derzhavnoi aviatsiinoi sluzhby Ukrainy za 2019 rik" $^{\prime \prime}$ [Report of the Head of the State Aviation Service of Ukraine for 2019]. https://www.kmu.gov. ua/storage/app/sites/1/17-civik-2018/zvit_2019/zvit2019-avia.pdf

Zhavoronkova, G., Zhavoronkov, V., and Volvach, N. “Development of the aviation transportation market in Ukraine: problems and prospects". Trans \& Motauto World, is. 3 (2018): 116-120. https://stumejournals. com/journals/tm/2018/3/116.full.pdf

Zhavoronkova, H. V. et al. Stratehichne upravlinnia aviatransportnymy pidpryiemstvamy [Strategic Management of Air Transport Enterprises]. Kyiv: Kondor, 2012. 